\title{
The transposition of the 2014 EU Directives on public procurement by Portugal: woes and expectations
}

\author{
Luís Valadares Tavares
}

\begin{abstract}
The new EU Directives on Public Procurement are oriented to promote the application of the concept of strategic public procurement which has been subject to several communications and discussions promoted by the European Commission and European Parliament. This new approach to Public Procurement has deep implications in the legal framework adopted by each Member State as well as in the public administration culture and organization in order that the new objectives of promoting the qualification of markets, the increase of innovation, the respect by social cohesion and environmental sustainability and a better access to public markets by SME's will be achieved aligned with the UE 2020 Agenda.

In this paper, the process and the results of the transposition of this Directives by Portugal are studied not just in terms of the respect for the Directives rules but also considering its likely positive and negative impacts on Portuguese public markets which are also synthetically described herein.
\end{abstract}

\section{Keywords}

public procurement; EU directives; strategic procurement; MEAT; innovation

\section{Previous legal framework}

Portugal has a very rich tradition of Public Law based on several prestigious Faculties of Law (see, namely, Faculty of Law of the University of Lisbon- www.fd.ulisboa.pt; Faculty of Law of the Portuguese Catholic University: Lisbon Centre - http://fd.lisboa.ucp.pt/pt-pt and Porto Centre http://www.direito.porto.ucp.pt/ and Faculty Law of the University of Coimbrahttps://www.uc.pt/fduc) giving special attention to the area of public contracts and since the forties the legal framework sets up very extensive and detailed rules about the formation of public contracts. Portugal has a Latin culture of public administration, public law and civil law, so the theory of administrative contracts [Assis Raimundo, 2013] has been quite important to rule the execution of contracts of public works until 2008 when a new code of public contracts (Código dos Contratos Públicos, CCP- Decreto-Lei 18/2008 de 29 de Janeiro) was approved extending such approach to the execution of contracts concerning the acquisition of supplies or services.

The theory of administrative contracts is not part of EU directives and includes a set of rules giving additional governing power to the contracting authority about the contract execution covering a wide spectrum of decisions that can be imposed to the contractor.

It should be noted that in Portugal, before the seventies, public procurement would account for less than 5\% of GDP and public works were the most complex contracts because there were no innovative technological services and acquired goods were quite basic. Public works contracts were based on execution design and very rarely the design and the execution were procured together as that was possible just in exceptional conditions.

The major procedures were the invitation (to at least 3 economic operators of the contract value not exceeding a specific threshold) and the open or restricted competition. 
Since 1986, Portugal is a member of EU and the history of our successive laws on public procurement shows unquestionably that such evolution has been triggered or even enforced by the successive waves of EU procurement directives.

Special attention was given to the Directives of 2004 and the new code, CCP, was approved modernizing and integrating two existing different laws, one for public works (Decreto-Lei 59/99) and another for goods and services (Decreto-Lei 197/99) and introducing important changes:

a) The theory of administrative contracts is extended to the execution of public contracts concerning the acquisition of goods and services (Part III of CCP on the execution of public contracts);

b) The major criterion to select a procedure according to the Directives is based on the "estimated contract value" but CCP replaced this concept by a different notion: "Preço-Base" (Article $47^{\circ}$ ) or maximal price that has to be defined at the beginning the process of contract formation and that has to be respected at the contract award and contract signature stages. This restriction is aiming to reduce uncertainty, but it is quite demanding for the contracting authority because setting up the "Preço -Base" can be quite a hard job. Furthermore, this restriction has also negative impacts on the levels of flexibility and innovation required in modern public procurement;

c) An wider range set of procedures were introduced: (Open, Restricted, Negotiated Procedures; Competitive Dialogue, Framework Agreements and Dynamic Purchasing Systems) in Part II of CCP but, unfortunately, the case of framework agreements with multiple contractors and full specification of contract object was not transposed because the concept of Quasi-Market [Tavares, 2009, a)] was not known by the authors of the law text (Article $252^{\circ}$ );

d) A procedure based on Invitation ("Ajuste Direto") without having to be sent to a minimal number of economic operators (Article $114^{\circ}$ ) was introduced for any contract with value not higher than $75000 €$ for goods and services or $150000 €$ for public works, which are the highest thresholds for invitation procedures in EU without a minimal number of invited economic operators. The previous law restricted the invitation procedure to much lower thresholds and a minimal number of three economic operators had to be invited;

e) A simplified invitation just requiring the acceptance of the invoice concerning the contract to be paid is also introduced for goods and services if the contract value does not exceed 5000 euros (Article 128 ${ }^{\circ}$ );

f) A multiple criteria linear additive model (see [Tavares, 2009, b)] [Tavares et al., 2008]) was introduced to apply the most economic advantageous tender (MEAT) requiring full specification of the structure, function and parameters of such model to be included in the procedure documents (Articles $73^{\circ}, 74^{\circ}, 75^{\circ}$ and $139^{\circ}$ ) if the procedure is not based on an invitation. These requirements have contributed to achieve a level of specification, transparency and equity much higher than the level prescribed by the Directives and adopted by other member States.

g) Abnormal tenders were identified in terms of a percentage of their price as a percentage of the "preço-base" (lower or equal to $60 \%$ for public works or $50 \%$ goods and services, Article $71^{\circ}$ of CCP) and contracting authorities could change such percentages (Articles $115^{\circ}, 132^{\circ}$ and $189^{\circ}$ ) but they had to justify such changes and so these percentages have been generally adopted. Obviously, such high and uniform percentages have been responsible for smashing the price of many tenders with quite devastating effects on several economic sectors and on the normal completion of many public contracts; 
h) Mandatory e-procurement was established [Arantes et al., 2013] for the formation of any contract using an electronic platform (Article $62^{\circ}$ ) excepting the cases based on an invitation. This was the first example of mandatory e-public procurement in EU based on the new concept of electronic platform (SAAS- Software as a Service) and it has been considered a remarkable success inspiring the mandatory adoption of e-public procurement since next October by the new 2014 Directives.

i) A national Portal - BASE (www.base.gov.pt) - was established (Article 465) where any notice has to be posted concerning the formation and execution of the contract avoiding the usual practices in most European States of disseminating such information through a high number of heterogeneous sites.

j) A complex and quite restricted set of rules were enforced concerning the introduction of contract modifications during its execution for public administrative contracts (Part III of CCCP).

k) The execution of contracts was studied in great detail for public works (more than 70 articles!) but for the case of the execution of the contracts concerning the acquisition of goods and services it was just stated that they should follow such rules "under the required changes" (Article $454^{\circ}$ $6)$.

An extensive analysis of CCP adopting a systemic approach is presented in [Tavares, 2016,a)]. Between 2008 and 2016, CCP was subject to successive minor changes and its application during 8 years allows the identification of positive and negative impacts:

\section{A- Positive impacts}

- The transposition of new procedures has rejuvenated the formation of public contracts

- The adoption of the multi-criteria additive linear model has introduced a higher level of transparency and equity in the process of tender evaluation

- E-Procurement was a strong factor to achieve higher competitiveness and wider participation in public markets also reducing the time and cost of the bureaucratic load [Costa et al., 2013] [Tavares, 2011, a)]

- The new portal BASE set up by the national regulator for public contracts (IMPIC- Instituto dos Mercados Públicos, do Imobiliário e da Construção, www.impic.pt) has been a significant factor for more transparency and democratic public audit of public procurement expenditure as all relevant information about public contracts is now publicly available and easily accessible.

\section{B- Negative Impacts}

- Lack of competition due to high thresholds allowing invitation to one single economic operator;

- Excessive bureaucratic load to form and to execute contracts, particularly if classified as administrative contracts, and lack of flexibility to manage change and innovation;

- The abnormal tender rules combined with the frequent adoption of minimal price award criterion have been responsible for the pathologic situation of having most tenders with a price equal to the abnormal minimal price and so the process of contract award becomes based on absurd rules (the first tender to be presented, etc.)

- Such rules based on unreasonable and uniform percentages had a dramatic impact on price smashing responsible for lack of quality and unfeasibility of many contracts. Also, such rules combined with systematic and long payment delays by contracting authorities exceeding all reasonable and legal limits have been responsible for the destruction of a significant of percentage of Portuguese companies during the financial crises of 2009-2013. 
Since 2009, an interdisciplinary society on public markets (APMEP - Associação Portuguesa dos Mercados Públicos - www.apmep.pt ) embracing the participation of some the best reputed lawyers, economists, managers, public procurers and ICT experts has been contributing to the improvements of public markets and the dissemination of e-procurement through several initiatives, namely the international e-public procurement conferences [Tavares, 2013] [Tavares, 2014] vas well as the annual national conferences on e-public procurement also supported by the national regulator, IMPIC and the Portuguese "Tribunal de Contas" (equivalent to the UK "National Audit Office" or the French " Cour des Comptes") and private firms, namely the electronic platform -VORTAL (www.vortal.pt) .

APMEP has also launched the EUROPEAN JOURNAL OF PUBLIC PROCUREMENT MARKETS (www.eupublicmarkets.com) being the first issue published on 2018.

\section{The Process of Transposition}

After being published the Directives of 2014, the Portuguese Government (XIX Constitutional Government) set up a working group coordinated by the head of the Portuguese regulator of public contracts, IMPIC (Institute of Public Markets, Real Estate and Construction), to prepare the proposition of legal changes and that group has preferred to amend present law rather than to prepare a new one. Unfortunately, this work was not grounded on any independent diagnosis or evaluation of the application of existing law as it has happened in other Member States, such as Italy, England, Scotland, Denmark, etc. This Cabinet finished his office on 2015 and no report of this Group is known but the new Government starting office on October 2015 set up on the beginning of 2016 another working group just including professors of administrative law and, once again, the president of IMPIC. Initially, the chair of this Group, Prof. Maria João Estorninho, prepared a proposal developing a new law following the soft law approach which implies a more compact text to be followed by additional regulations, but the Government rejected this work and then another process has been started based on the office of the Secretary of State of Infra-Structures to prepare the amendments to the 2008 law. The draft version was circulated on August 2016 generating a wave of suggestions and criticisms and, finally, the new law was published on August 2017-: Decreto-Lei 111-B/2017 (https://dre.pt/application/file/a/108085917) requiring already two corrections due to editing or consistency errors published on 30th October of 2017 (https://dre.pt/application/file/a/114133073) and 30th of November 2017 (https://dre.pt/application/file/a/114290199).

\section{Strategic Public Procurement: Cultural and Policy Issues}

The scope of the new Directives [Tavares et al., 2014] is not just contract awarding but the whole process of public procurement and its aim is to redirect public procurement [Estorninho, 2016] according to the key concept of strategic public procurement well described by the European Commission :

"Public procurement is a strategic instrument in each Member State's economic policy toolbox. The 2015 single market strategy made the case for more transparent, efficient and accountable public procurement systems. This requires a shift from a purely administrative approach to a strategically and needs-driven approach, in full compliance with the rules. With roughly $14 \%$ of the EU GDP in expenditure each year, public procurement can contribute to address many of Europe's major challenges, especially in creating sustainable growth and jobs. It can enable investment in the real economy and stimulate demand to increase competitiveness based on innovation and digitalisation, as highlighted in the Industry Communication. It can also support the transition to a resourceefficient, energy-efficient and circular economy and foster sustainable economic development and more equal, inclusive societies." [European Commission, 2017] 
under the paradigm of pursuing the road map of the Agenda EU 2020 to increase the societal value of public procurement [Piga and Thai, 2007] [Cunha Rodrigues, 2015].

Unfortunately, the described process did not provide opportunity to interdisciplinary contributions on key areas underlined by the Directives such as Innovation, Quality/Price Multicriteria Evaluation, Digital Economy, Environmental Sustainability, Social Cohesion or even New Public Management. This lack of contributions is clearly shown by several examples:

a) The innovation challenge [Tavares, 2018, and Tavares, 2016, b)], namely concerning the ability to adapt the contract to new conditions, is not properly tackled and the rule of the "PreçoBase" (maximal contract price set up in the beginning of the procedure, Article $47^{\circ}$ ) keeps its mandatory nature. This approach is in contrast with the Directives concept of "estimated value" and the possibility to be corrected in innovative contracts as it is quite clear in several codes.;

b) The clear preference of the Directives for a multi-criteria evaluation of tender is not respected as the Article $74^{\circ}$ states the adoption of the Most Economically Advantageous Tender (MEAT) but, quite surprisingly, considers that such formulation include the minimal price criterion(!). The concept of tender evaluation model has not been well understood by some authors as it is not considered as a pre-condition for any evaluation process but just existing if multi attributes are considered (see [Gonçalves, 2018] 126.1 p788). Obviously, as it could be also expected, the difference between a multi linear attribute model and the multiplicative model (quality/price) is simply ignored, also by several authors with expertise in public law but without expertise in Decision Theory (see [Gonçalves, 2018] [Amaral e Almeida, 2016) and [Almeida, 2016]. Furthermore, the mandatory adoption of the award criterion of ratio quality/ price for the competitive dialogue or partnership for innovation established by the Directives in the Articles $30^{\circ}$ and 31 , was ignored too and so it is an evident transposition error which can be the source of unnecessary litigation.

c) Portugal had a pioneering role through the mandatory adoption of electronic procurement in any procedure not based on invitations from November 2009 and so another more ambitious step could have been expected but that was not the case, probably due to the lack of technologic background of the authors contributing to the law (Article 115 $-1 \mathrm{~g}$ ) of DL 111-B/2017). Even the adoption of mandatory electronic contracts (Article $94^{\circ}$ to $106^{\circ}$ ) or e-invoices (Article $299^{\circ}$ B-5 of DL 111-B/2017) was not yet fully clarified. The rules concerning the electronic catalogues (Annex XIV of DL 111-B/2017) were introduced in the last minute as annex, perhaps to avoid disturbing the law text;

d) New public management was taken into account by EU Directives since 2004 through innovative concepts such as the framework agreements with multiple contractors (Quasi-Market) allowing to give back to the citizens the decision power to select the provider but the authors of 2008 law did not understand the concept and the proposed version by present Government made the same mistake, despite the clear explanation of the Recital 61 of the Directive 2014/ 24/ EU. Fortunately, the recommendation of APMEP (Portuguese Society of Public Markets, www.APMEP.pt ) was accepted and the published law allows such important procedure.

e) Similarly, a correction was introduced about the domain of application of the Dynamic Purchasing Systems as the initial version of the code was not considering the new scope established by the Directives (Article $34^{\circ}$ ) but the proposition of APMEP was accepted and the new Article $237^{\circ}$ of DL 111-B/2017 was improved enlarging the domain of application to small public works. Unfortunately, the restriction of "standardized goods and services " which is no longer required by the Article $34^{\circ}$ of the Directive 24/2014/UE is kept by the Article $237^{\circ}-1$ DL 111-B/2017. 
The option of not preparing a new law from scratch was initially supported by many lawyers and professors of Law under the expectation that amendments would be minor and few. However, the final result includes:

a) New articles: 54

b) Revoked articles: 34

c) Amendment articles: 155

which means that about $51 \%$ of the code was changed.

The final result includes about 500 articles being considered one of the most long (just comparable to the Greek and Spanish ones) and complex codes of the EU. Unfortunately, several errors or limitations concerning the transposition of the Directives can be pointed out and should be corrected as it is clear from Annex 1.

\section{The Portuguese Public Markets}

The Portuguese public markets are quite an important dimension of national economy because about 65000 economic operators have direct public contracts and, in average, two key sub-contracts are associated to each public contract, obtaining a population of about 200000 firms relying on public markets of a total of about 350000 firms and the estimated value of public contracts exceeds $14 \%$ of GDP.

In the next figure (See Figure 1) key features of these public markets are presented:

and the following conclusions can be obtained: 


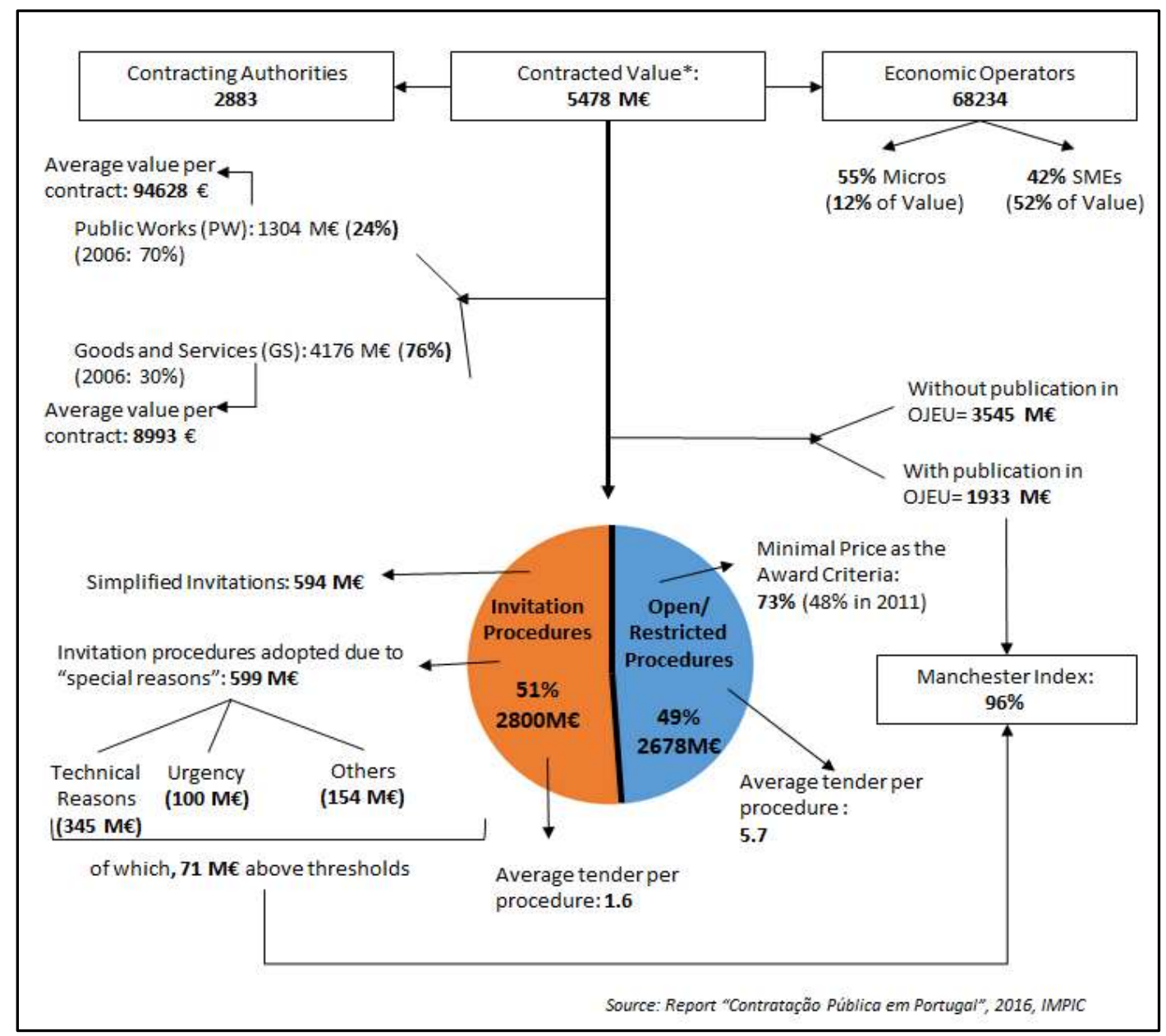

Figure 1 - Portuguese Public Markets, 2016

A- Most the contract value does not concern public works as it was in the past (about $70 \%$ in 2006) but nowadays the major class concerns services (ICT, health, etc.);

B- Most of the contracted value is awarded through direct invitation obtaining a low average number of tenders per invitation (1.6) which means that there is a clear lack of competition;

C- There is also a significant awarded value by direct invitation through contracts with a value exceeding the EU thresholds (71 million $€$ ) based on special reasons such as urgency, secrecy, exclusivity or property rights, etc. explaining why the Manchester Index [Tavares, 2017] is not $100 \%$ for Portugal as it could be expected.

\section{Impacts of the new code on Portuguese public markets}

Despite all limitations and shortcomings already pointed out, the amendments due to the new rules imposed by the Directives, can open new avenues for improvement of Portuguese markets and so a positive and optimistic attitude should be adopted overcoming the problems discussed in previous section:

\section{a) More competition and participation}

The full use of the electronic platforms can help to increase competition [Tavares, 2011, b)] through wide spread invitations to registered economic operators able to cope with the contract to be awarded by the contracting authority. This process is generally called "Request for Invitation" because it is a preliminary stage of the invitation that it will be sent to the selected economic operators. 
A good illustration of more extensive use of direct award through e-platforms is the case of the Health Ministry since the innovative decision of January 2017 (Despacho $N^{o} 851-A / 2017$ of 13 January of Ministry of Health published on Diário da República $N^{\circ} 11$, $2^{a}$ série, 16 January)

Another efficient way to increase competition for recurrent acquisitions is the adoption of Dynamic Acquisition Systems avoiding the traditional invitation to just the few usual ones.

Also, electronic catalogues can help significantly as an addition to framework agreements or dynamic purchasing systems.

The upper bound for financial qualification (Article 165-3 of DL 111-B/2017) and the need to adopt lotting in most cases (Article $46^{\circ}$-A of DL 111-B/2017) can also help to have more participation of SMEs.

\section{b) More innovation}

The adoption of specifications based on performance indicators and award criteria covering the full spectrum of relevant attributes can open wide opportunities for innovative tenders. Appropriate procedures can be now used to include key stages for improving the contract object to be awarded and to negotiate the best solution, such as open procedure with negotiation, competitive dialogue or partnership for innovation. This approach will be very favorable to attract SMEs as they tend to be more prone to innovation.

Of course, the award criterion of minimal price with full specification of all the other attributes should be avoided as it is a barrier to any innovation.

\section{c) More "Good Value for Money"}

A quite general criticism about public procurement is based on the deficient value for money achieved despite the long and complex procedures to form a public contract but the new approach to formulate the award criterion considering the whole range of expected benefits, the professional abilities of who is executing the contract, the post sales needs and services, the life cycle costing and the environmental impacts can help to avoid usual myopic or just price based approaches .

\section{d) Better management of the contract execution and its performance evaluation}

The Portuguese code establishes the need to have appointed a contract manager in charge of managing the process of contract execution including the estimation of the performance indicators to allow the evaluation of the contract execution (Article 290'-A of DL 111-B/2017).

Hopefully, such evaluation will be an incentive to improve performance of contractors and to select them in a better way.

Also, the new approach based on "performance-based contracting" can be more easily adopted introducing internal contract feed-backs to reduce the risk of lower levels of performance.

The new rule of exclusion of candidates associated to previous bad performance (Article $460^{\circ}$ of DL 111-B/2017) is now applicable although the author believes that its application will be subject to generalized litigation.

\section{e) Better regulation}

Portugal was also pioneering public contracts regulation though the establishment of IMPIC since 2009. All contract notices and award notices have to be published through its portal and a national report on public procurement is annually published avoiding the usual data fragmentation of most member States (Spain, England, France, Italy, etc.). 
The new Directives specify new roles and duties in the areas of support to better practices, reporting and auditing and so new competences and more resources should be allocated to IMPIC.

\section{Conclusions}

Portugal had an advanced- although too complex-code since 2008 but has not used the opportunity of having to transpose the new Directives to prepare a modern and consistent code because preference for an amendment approach prevailed. Also, a pure public law culture was considered and therefore other inter-disciplinary contributions were not integrated.

Still, important advances and improvements can be applied because the new law has transposed most of the Directives new rules and so public markets will be improved if properly applied. This objective implies extensive training of public procurers following the paradigm of their professionalization well described by the European Commission in Recital 121 of the Directive 2014/24/UE and the EU Recommendation [European Commission, 2017]

"... This Recommendation encourages the development and implementation of professionalization policies in the Member States, by offering a reference framework for consideration. The desired outcome of this initiative is to help Member States to build the policy for professionalization to increase the profile, influence, impact and reputation of procurement in delivering public objectives."

However, an estimated number of staff working on public procurement for contracting authorities is about 20.000 and the number of those having already received any training - even if just on legal matter - about the new Directives and Code is not exceeding 600 and so more than $97 \%$ of our officers have not received any specific training. This situation is in contrast with good examples of national training programs embracing most the relevant public officers and organized in several member States such it is the case of Italy [Guidi, 2018].

Summing up, new public policies of training and of modernizing public procurement are critical to pursue the path designed by the Agenda UE 2020 and inspiring the new Directives of 2014 and aiming to achieve the paradigm of more sustainable, coherent and digital development which should make the best use of all the positive changes introduced by DL 111-B/ 2017.

\section{References}

- Almeida, T., 2016, Critérios de adjudicação - o (novo) conceito de oferta economicamente mais vantajosa, Revista dos Contratos Públicos, nº 13, 109-141.

- Amaral e Almeida, J., Sánchez, P.F., 2016, Comentários ao anteprojecto de revisão do código dos contratos públicos, Regime da Contratação Pública, Sérvulo \& Associados.

- Arantes, A., Costa, A.A., Tavares, L.V. 2013, The evaluation of mandatory e-public procurement in Portugal: perceptions and results of the national survey (2010-2012) in Tavares, L.V., ed., 2013, Proceedings of the 1st European Conference on e-Public Procurement (ECPP): E-Public Procurement in Europe : Public Management, Technologies and Processes of Change, OPET.

- Assis Raimundo, M., 2013, A Formação Dos Contratos Públicos. Uma Concorrência Ajustada Ao Interesse Público, AA FDL.

- Costa, A.A., Arantes, A. e Tavares, L.V., 2013, Evidence of the impacts of public e-procurement: the portuguese experience, Journal of Purchasing and Supply Management, 19(2013), pp. 238246.

- Cunha Rodrigues, N., 2015, A contratação pública como instrumento de política económica, Tese de Doutoramento, Almedina Brasil. 
- Estorninho, M.J., 2016, A transposição das Diretivas europeias de 2014 e o Código dos Contratos Públicos: por uma contratação pública sustentável e amiga do bem comum em Estorninho, M.J, ed., A Transposição das Diretivas Europeias de 2014 e o Código dos Contratos Públicos, 2016, Instituto de Ciências Jurídico-Políticas.

- European Commission, 2017, Commission Recommendation (EU) 2017/1805 of 3 October 2017 on the professionalisation of public procurement - Building an architecture for the professionalisation of public procurement, C/2017/6654, European Commission

- European Commission, 2017, Communication From The Commission To The European Parliament, The Council, The European Economic And Social Committee And The Committee Of The Regions Making Public Procurement work in and for Europe, COM/2017/0572 final, European Commission

- Guidi, V., 2018, The transposition of the 2014 Directives on public procurement into the Italian law: a challenge for a deep reform of the Italian public procurement system, European Journal of Public Procurement Markets

- Piga, G., Thai, K., 2007, The Economics of Public Procurement, Macmillan.

- Tavares, L. V., Coelho, J.S, Maia, P., 2008, O Modelo e o Software SIAP 2008 para avaliação de propostas e candidaturas segundo o Código dos Contratos Públicos (DL18/2008), OPET.

- Tavares, L.V., 2009, a), A Gestão das Aquisições Públicas: Guia de Aplicação do Código dos Contratos Públicos - Decreto-Lei 18/2008 - Empreitadas, Bens e Serviços, OPET.

- Tavares, L.V., 2009, b), A avaliação das propostas segundo as Diretivas 2004/17/CE e 2004/18/CE e o código dos contratos públicos, Revista do Tribunal de Contas $\mathrm{n}^{\circ} 50 / 56$, julhoDez 2008 .

- Tavares, L.V., 2011, a), A business case on innovative health procurement how to provide better services using a lower budget by a major oncology hospital?, IESE, Madrid.

- Tavares, L.V., 2011, b), A strategy to reduce public expenditure based on e-tendering and procurement business inteligence: the case of Portugal, Vortal.

- Tavares, L.V., ed., 2013, Proceedings of the 1st European Conference on e-Public Procurement (ECPP): E-Public Procurement in Europe : Public Management, Technologies and Processes of Change, OPET.

- Tavares, L.V., ed., 2014, Proceedings of the 2nd European Conference on e-Public Procurement (ECPP): New Developments on E-Public Procurement, OPET.

- Tavares, L.V., Medeiros, R., Coelho, D., 2014, "The New Directive on 2014/24/UE on Public Procurement", OPET

- Tavares, L.V., 2016, a), Breve ensaio sobre a teoria dos sistemas e o código dos contratos públicos, em estorninho, M.J, ed., A Transposição das Diretivas Europeias de 2014 e o Código dos Contratos Públicos, 2016, Instituto de Ciências Jurídico-Políticas.

- Tavares, L.V., 2016, b), A Transposição da Nova Diretiva 2014/24/EU Relativa aos Processos de Aquisição de Bens, Serviços e Obras Baseados em Contratos Públicos: Concorrência e Inovação, Revista do Tribunal de Contas, nº63/64, Janeiro/Dezembro 2015.

- Tavares, L.V, 2017, O Guia da Boa Contratação Pública: As Diretivas e o DL 111-B/2017, OPET 
- Tavares, L.V., 2018, Public Procurement of Innovation: A cultural challenge, European Journal of Public Procurement Markets 


\section{Annex 1 - Major limitations or errors of the transposition of the new Directives by Decreto-Lei 111-B/2017}

1. The approved Code does not cover the transposition of the Directive 2014/23/UE because the Article $429^{\circ}$ states that regime of concessions of public services will be ruled by a new specific law;

2. The Article $29^{\circ}$ of the Code is not a correct transposition of the Article $26^{\circ}-4$ a) of the Directive 2014/24/UE that states that "(a) with regard to works, supplies or services fulfilling one or more of the following criteria: (i) the needs of the contracting authority cannot be met without adaptation of readily available solutions; (ii) they include design or innovative solutions." while the Article $29^{\circ}$ of the Code just refers to "goods or services that include the design of innovative solutions" (Article 29 -1 b)). Obviously, this second condition is more restrictive than the one adopted by the Directive as it does not mention public works and because there is a wide scope of innovative contracts not including any conception but rather new approaches concerning the adopted materials, the execution processes, the combination of products, etc.

3. The Article $237^{\circ}-1$ of the Code about Dynamic Purchasing Systems introduced the restriction of concerning goods or services of "current use" but the Article $34^{\circ}$ of the Directive $24^{\circ}$ does not introduce this restriction.

4. The Article $74^{\circ}-1$ b) of the Code includes the award criteria based on the minimal price as a case of the general criteria of the most economically advantageous tender (MEAT) which is an obvious mistake.

5. The Directive $2014 / 24 /$ UE states in Article $30^{\circ}$ and $31^{\circ}$ that the award criteria adopted for the competitive dialogue and the partnership for innovation must be the ratio quality/price but the Code forgets this requirement.

6. The Article $115^{\circ}-2 \mathrm{~b}$ ) of the Code concerning the award criteria to be adopted for the procedures based on invitation (Direct Award) does not require the specification of the weight coefficients allocated to the different attributes. However, the Article $67^{\circ}-5$ of the Directive 2014/24/UE states that such coefficients should be presented as a general rule.

7. The Article $115^{\circ}-1 \mathrm{~g}$ ) of the Code concerning the communication means adopted for the invitation procedure allows the use of "data electronic transmission" without further requirements and so a common email seems to be allowed. However, the Directive 2024/24/UE in the Article $22^{\circ}-3$ is clear about the requirements of confidentiality and integrity to be respected by such means which are not fulfilled by common emails.

8. The Article 5-A-2 of the Code concerning "horizontal in-house contracting" as forgotten to specify the restrictions applicable to eventual private participation in the capital of the contracted authority and so, such restriction of Article $12^{\circ}$ of the Directive 2024/24/UE is not mentioned.

9. The Article $198^{\circ}-3$ of the Code mentions that the deadlines for candidates of the Negotiation Procedure can be reduced by 7 days if using electronic means which is absurd because this means should be now used always, and such reduction which was mentioned in the Directive 2004/18/CE is not included in the new Directives. 